\title{
Infra-red spectroscopy reveals chemical interactions driving water availability for enzyme activities in litters of typical Mediterranean tree species
}

\author{
Anne Marie Farnet-Da Silva*, Elisée Ferré, Nathalie Dupuy, Auriane de la Boussinière, \\ Catherine Rébufa \\ Aix Marseille Univ, Univ Avignon, CNRS, IRD, IMBE UMR 7263, Marseille, France
}

\section{A R T I C L E I N F O}

\section{Keywords:}

Hydric stress

Lipases

Osmotic stress

Sorption isotherms

Water activity

\begin{abstract}
A B S T R A C T
In Mediterranean ecosystems, water is one of the main drivers of the microbial activities that support organic matter turnover in soils or litters. In addition to drought stress, coastal areas are subject to osmotic stress linked to sea spray exposure. Here we explored i) how water availability, characterized by water activity $a_{w}$, is impacted by adding $\mathrm{NaCl}$ to litter, ii) the chemical interactions between water, $\mathrm{NaCl}$ and the litter matrix and iii) whether microbial activities (using lipase as a model) are affected under these conditions. Litters of two vegetal species typical of the Mediterranean area (Quercus pubescens and Pinus halepensis) were subjected to FTIR-ATR (Fourier-Transformed Infra-Red - Attenuated Total Reflectance) spectroscopy for chemical characterization. Q. pubescens and P. halepensis litters were characterized by cutin and aromatics respectively. Sorption isotherms were identical for both species litters; when $\mathrm{NaCl}$ was added, a shift in isotherm shape was observed at $\mathrm{a}_{w}$ ranging from 0.75 to 1 . FTIR also discriminated samples with and without added $\mathrm{NaCl}$ and revealed that cellulose is probably the polymer in interactions with ions. Very interestingly, no differences were found between lipase hydrolytic activities with and without added $\mathrm{NaCl}$ : salt addition had no effect on these activities.
\end{abstract}

\section{Introduction}

Mediterranean ecosystems are known to be subject to severe climate constraints, mainly intense summer drought. Predicted climate change is expected to aggravate these conditions (Giorgi and Lionello, 2008). The question is whether saline environments, such as coastal zones, may be more constrained and thus potentially weakened under the threat of climate change. Water availability is indeed further hampered in the soils and litters of coastal areas by an additional stress specific to these environments, i.e. osmotic stress via sea spray exposure. Thus, water is the main environmental factor influencing organic matter decomposition in Mediterranean ecosystems (Coûteaux et al., 1995).

Litter decomposition is a vital process that ensures nutrient turnover. Microbial communities (both bacteria and fungi) play a crucial role in organic matter recycling, through the various extracellular enzymes they produce. The quantity of water

\footnotetext{
* Corresponding author.

E-mail address: anne-marie.farnet@imbe.fr (A.M. Farnet-Da Silva).
}

available strongly influences the structure and composition of microbial communities and their metabolism (including extracellular enzyme production). At molecular level, water availability also affects the diffusion of substrates and the catalysis of hydrolytic enzyme reactions. In most studies, water is characterized as moisture, but this measurement is not informative enough when there is a low quantity of water, as observed in soils or litters from arid areas. A useful alternative parameter to precisely determine water availability under such conditions is water activity, $a_{w}$, the ratio of vapor pressure of a material to vapor pressure of pure water. This can provide information about the quantity of 'free' water molecules available for biological processes. Our previous study, (Farnet et al., 2013), first described the pronounced effect this parameter has on the balance of certain enzyme reactions (hydrolysis/synthesis), and the consequences for carbon mineralization or storage. Certain enzymes such as lipases are indeed able to catalyze either hydrolysis or synthesis according to water availability, since water is a substrate of the reaction (Goujard et al., 2009; Farnet et al., 2010). Thus, under the particular conditions linked to arid climates, water activity can be 
considered as a useful parameter to clearly understand enzyme activity dynamics.

The present study aimed to explore how additional matric stresses, such as osmotic stress, may alter hydric conditions in litters and thus microbial functioning. A further aim was to clarify the molecular mechanisms underlying water availability in litter, to determine whether certain vegetal species may favor water retention depending on their chemical signature. To do so, FTIRATR (Fourier-Transformed Infra-Red - Attenuated Total Reflectance) spectra were used to precisely describe water and $\mathrm{NaCl}$ adsorption onto plant polymers, and thus to determine how the chemical composition of litters from different vegetal species may modify their water availability. FTIR spectroscopy is well recognized for its ability to characterize the chemical structure of plant samples by identifying key compounds from different parts of the plant, such as polysaccharides (Kačurčáková et al., 2000, lignin (Boeriu et al., 2004), and cuticular waxes (Dubis et al., 1999). The review of Heredia-Guerrero et al. (2014) summarized the main applications of Infrared and Raman spectroscopies to characterize plant cuticle and its components (cutin, waxes, polysaccharides and phenolics) in terms of assignment of the functional groups present in the cuticular matrix, interaction and macromolecular arrangement. Infrared spectra of litters can be very complex, because their macromolecular organic composition generates complex interactions with surrounding compounds or between their functional groups. The review of Fan et al. (2012) described the use of FTIR to examine the formation of inter- and intramolecular hydrogen bonds in celluloses, investigating the effects of deterioration (crystallinity vs amorphous structure) and the change in chemical composition of major (cellulose, hemicellulose and lignin) and minor (pectin and waxes) constituents after decomposition.

We also determined sorption isotherms to describe the relationship between humidity and water activity, at different $\mathrm{NaCl}$ concentrations and without added $\mathrm{NaCl}$, for litters of two typical Mediterranean plant species: Pinus halepensis and Quercus pubescens. The main environmental constraint in Mediterranean ecosystems is summer drought (Castro et al.,2008; Sofo et al., 2008), but coastal zones also experience windy conditions, higher temperatures, and additional stresses, such as osmotic stress due to sea spray exposure, which can further impact litter functioning (Qasemian et al., 2014). Hydrolytic lipase activities were measured in litters both with and without added $\mathrm{NaCl}$, and at different $a_{w}$. These activities offer a particularly reliable way to investigate the effect of water availability on enzyme catalysis, since this enzyme reaction is performed in apolar organic solvents and therefore water quantity can easily be controlled. While many studies have examined extracellular enzymes involved in litter transformation in inland areas under a Mediterranean climate (Fioretto et al., 2009; Papa et al., 2008), few have investigated whether the enzymatic reaction may be affected by the salts present in coastal zones.

\section{Materials and methods}

\subsection{Litter sampling}

Litters of Quercus pubescens (QP) and Pinus halepensis (PH) were collected in the form of two composite samples for each species from three independent sites (La Quille, Le Coucou, Le Castellas) in the Massif de la Trévaresse (Bouches du Rhône, France, 43 $37^{\prime} 7.31^{\prime \prime}$, $5^{\circ} 27^{\prime} 41.56^{\prime \prime}$ ) in February 2015. At each site, three sampling plots of $500 \mathrm{~m}^{2}$ were determined, and horizon $\mathrm{F}$ was collected for both litters. All the experiments described below were performed for both QP and PH litters.

\subsection{Water activity and humidity}

Litter samples were reduced to powder using a bullet blender Retsch MM40 (Fisher Scientific, France). Water activities of the litter powders, as well as temperature, were measured with a HygroPalm 23-AW-A (Rotronic AG, Bassersdorf, Switzerland) portable analyzer equipped with a WP-40 sample holder. Water activity, $a_{w}$, was measured in an incubator at $25^{\circ} \mathrm{C}$ using $4 \mathrm{~g}$ of litter (fresh weight). Litters were first hydrated to reach $80 \%$ of Water Holding Capacity, by adding $110 \mathrm{~mL}$ of water to $50 \mathrm{~g}$ of litter dry weight to reach $a_{w}=1$. Then, to obtain different $a_{w}$ values, litters were gently dried at room temperature (around $22{ }^{\circ} \mathrm{C}$ ). To test the effect of $\mathrm{NaCl}$, litters were similarly hydrated with solutions of $\mathrm{NaCl}$ (Sigma Aldricht) at different concentrations (35, 50, 75 and 100 g.L $\mathrm{L}^{-1}$ ) to reach $80 \%$ of Water Holding Capacity, in order to avoid percolation and optimize $\mathrm{NaCl}$ adsorption onto litter. $110 \mathrm{~mL}$ of $\mathrm{NaCl}$ solution were added to $50 \mathrm{~g}$ of litter dry weight and this protocol was used for each $\mathrm{NaCl}$ concentration. Then, $a_{w}$ measurements were performed as described above.

Humidity was measured after $48 \mathrm{~h}$ of incubation at $100{ }^{\circ} \mathrm{C}$ using $1 \mathrm{~g}$ of fresh litter and was expressed as percentage of water in fresh litter. The experiment was performed three times for each sample.

\subsection{Lipase hydrolytic activities}

Enzyme activities were measured from litters for different $a_{w}$ values as described by Farnet et al. (2010). This assay was adapted for litters from the method of Pencreac'h and Baratti (1996) using methyl $t$-butyl ether as the organic solvent of the reaction mixture. The mixture was composed of: $10 \mathrm{mM}$ of $p$-nitrophenyl laurate solubilized in $2 \mathrm{~mL}$ of methyl $t$-butyl ether and $1 \mathrm{~g}$ of litter. The reaction mixture was incubated at $30^{\circ} \mathrm{C}$ under magnetic stirring at $500 \mathrm{rpm}$ for $2 \mathrm{~h}$. Then, $500 \mu \mathrm{L}$ of the organic phase were added to $4 \mathrm{~mL}$ of $0.1 \mathrm{M} \mathrm{NaOH}$ and after a brief shaking, $p$-nitrophenol was measured at $412 \mathrm{~nm}$ in the aqueous phase with Spectrophotometer Biomate (Bioblock Scientific). The same protocol was used with litters supplemented with solutions of $\mathrm{NaCl}$ at different concentrations: 35, 50, 75 and 100 g.: $\mathrm{L}^{-1}$.

To test for any abiotic reactions, litters were autoclaved and $p$ nitrophenol release was checked.

Three replicates were performed for each experiment. Activities were expressed as $\mu$ moles of $p$-nitrophenol released/hour/g of dry weight. A calibration curve of $p$-nitrophenol in methyl $t$-butyl ether was performed with and without litter under the same experimental conditions.

All the chemical compounds of Rectapur quality were purchased from Sigma Aldrich and methyl $t$-butyl ether was used as purchased, without further purification.

\subsection{Chemical characterization of litters by FTIR-ATR (Fourier- Transformed Infra-Red - Attenuated Total Reflectance)}

Litter powders were directly deposited onto a Specac's Golden Gate $^{\mathrm{TM}}$ ATR Accessory of a Thermo Nicolet IS10 spectrometer equipped with a Mercury Cadmium Telluride (MCT) detector, an Ever-Glo source and a $\mathrm{KBr} / \mathrm{Ge}$ beam-splitter. Spectra were acquired between 4000 and $650 \mathrm{~cm}^{-1}$, with a $4 \mathrm{~cm}^{-1}$ nominal resolution. For each spectrum, 100 scans were co-added. A background spectrum in air (under the same acquisition conditions as those used for the samples) was acquired before each acquisition. The ATR crystal was carefully cleaned with ethanol to remove any residual traces of the previous sample. Three spectra were recorded for each sample. OMNIC 8.1 (Thermo Nicolet) was used to record FTIR-ATR spectra. The Unscrambler version 10.3 from Computer Aided Modeling software (CAMO, Trondheim, Norway) was used to perform data 
analyses. The spectral range of the absorption of the carbon dioxide was removed (between 2400 and $1900 \mathrm{~cm}^{-1}$ ) and then two preprocessing methods were applied: a standard normal variate (SNV) followed by an offset Baseline correction to remove from the spectra the slope variation caused by scatter and variation in particle size.

\subsection{Statistical analysis}

Two-way ANOVAs were performed on lipase activities, taking into account the addition of $\mathrm{NaCl}$, the vegetal species (Quercus pubescens and Pinus halepensis) and their interactions, followed by an LSD post-hoc test. A Student's $t$-test was also used to check whether two means differed significantly depending on species. Normality and homogeneity of variance were checked on the residual from the regression model using Shapiro-Wilk and Levene tests respectively. Data were transformed with log 10 when necessary to meet parametric ANOVA requirements in terms of normality and homogeneity of variance.

Principal Component Analysis (PCA) was used to detect variations in the spectral dataset in correlation with chemical characteristics of the litters, water activity of the samples and salt concentrations used to simulate different saline environments. Principal components (PC) were extracted with a full cross validation on centered and reduced data. PCA was used to facilitate the analysis of spectral information by grouping data into smaller sets and eliminating multi-collinearity between variables (wavenumber). This approach enabled us to explain the variance observed in the initial data set, by extracting a reduced number of principal components (PCs) defined as pure and simple mathematical transformations of the initial variables. PCA results were interpreted through the graphical representation of the sample in the factorial plane of the principal components (score plot) and those of the variables in the same factorial plane (loading plot). The sample grouping in the factorial plane was interpreted through their position (positive or negative) on one of the axes. In parallel, the examination of the PC loadings showed which spectral bands were predominant in the sample grouping, either in the positive or negative part of the PCs (Jolliffe, 2002).

\section{Results}

\subsection{Sorption isotherms in the two types of litter with and without added $\mathrm{NaCl}$}

Our first objective was to investigate how the relationship between humidity and water activity in litters may be affected by the presence of salts, and whether this depends on the vegetal species considered. Sorption isotherms were determined for the two plant species both with and without added $\mathrm{NaCl}$ (Fig. 1). The 'control' isotherms, without added $\mathrm{NaCl}$, were type-2 sigmoidal sorption isotherms as described by Brunauer et al. (1940), characterized by the presence of multilayers of water molecules at the surface. This means that at $\mathrm{a}_{w}$ ranging from 0 to 0.2 , water is strongly bound to the litter; from 0.2 to 0.6 , molecules of water are organized in multilayers; and from 0.6 to 1 , molecules of water are free or loosely bound to the external surface of the multilayer.

When $\mathrm{NaCl}$ was added to litters, at $\mathrm{a}_{w}$ ranging from 0.75 to 1 , a change in isotherm shape was observed; this increased with increasing quantities of salt. Thus, at above $\mathrm{a}_{w}=0.75$, saltcontaining litters absorbed more water molecules than in control, while below this value no changes in water sorption were observed. This reveals that above $\mathrm{a}_{w}=0.75$, for the same percentage of humidity, water availability was lower in salt-containing litters than in control. Interestingly, similar sorption isotherms were found

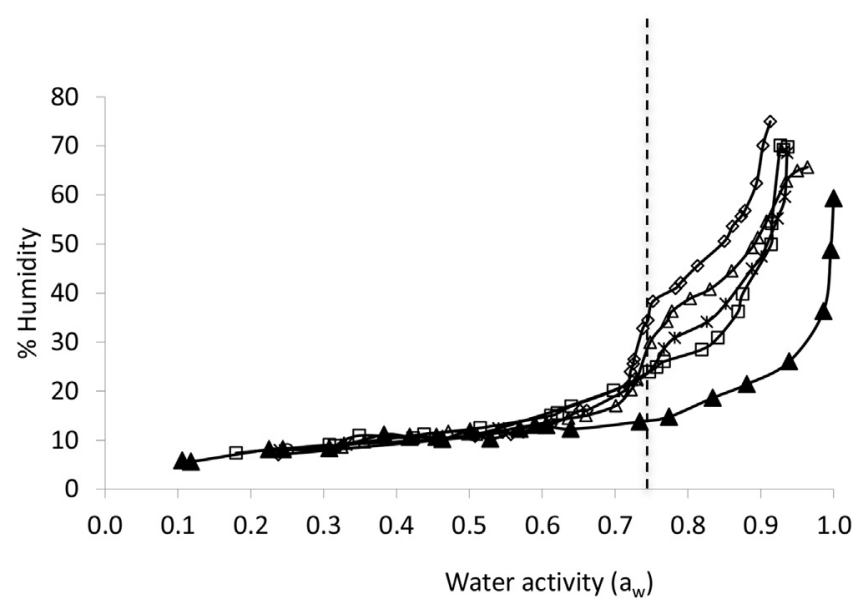

Fig. 1. Sorption isotherms for litters of Pinus halepensis without $\mathrm{NaCl}(\boldsymbol{\Delta})$, and supplemented with a solution of $\mathrm{NaCl}$ at $35(\square), 50(\times), 70(\Delta)$ and $100(\diamond)$ g.L. $\mathrm{L}^{-1}$. Identical patterns were found for Quercus pubescens and Pinus halepensis.

-both with and without added $\mathrm{NaCl}-$ for both the vegetal species considered, indicating that potential variations in the chemical signature of the litter do not modify water sorption/desorption dynamics.

\subsection{Litter chemical characterization using infrared spectroscopy}

To determine how chemical composition of litters impacts the interactions between water and the vegetal matrix, FTIR-ATR technique was used to characterize the two vegetal species. FTIRATR litter spectra of $P$. halepensis or $Q$. pubescens at $\mathrm{a}_{w}=0.4$ (Fig. 2) show a broad band around $3340 \mathrm{~cm}^{-1}$ assigned to the stretching vibration of H-bonded hydroxyl groups and due to the presence of intermolecular and intramolecular hydrogen bonding. Compounds of cuticle (polysaccharides, cutin and, to a lesser extent, waxes) and of lignin are the main compounds contributing to this band (Table 1). Two characteristic bands at 1238 and $1219 \mathrm{~cm}^{-1}$ can also be assigned to the bending vibration of hydroxyl groups of polysaccharides and cutin, and the intense, large band around $1029 \mathrm{~cm}^{-1}$ is mainly due to the stretching vibration of $\mathrm{C}-\mathrm{O}-\mathrm{C}$ glycosydic bonds in polysaccharides. The aliphatic chemical fraction of litters results in two bands pointed at 2918 and $2850 \mathrm{~cm}^{-1}$, characteristic of the asymmetrical and symmetrical stretching vibration of $\mathrm{CH}_{2}$ groups, as well as $\mathrm{C}-\mathrm{H}$ bending vibrations between 1450 and $1300 \mathrm{~cm}^{-1}$ and a $\mathrm{C}-\mathrm{H}$ rocking vibration at $719 \mathrm{~cm}^{-1}$. All these signals are thus characteristic of long aliphatic chains mainly found in cutin and waxes. In these molecules, carbonyl groups from esters and carboxylic acid associated with aliphatic chains were observed under the stretching vibration bands pointed at $1732 \mathrm{~cm}^{-1}$ and $1693 \mathrm{~cm}^{-1}$, with a C-O-C asymmetrical-stretching ester vibration band at $1167 \mathrm{~cm}^{-1}$. Pectins are polysaccharides rich in carbonyl groups, and these signals may therefore also be linked to such polymers. The bands in the 1600 $1500 \mathrm{~cm}^{-1}$ spectral region are related to aromatic and alkene functional groups from phenolic compounds and the spectral region between 900 and $800 \mathrm{~cm}^{-1}$ also provides information on aromatic $\mathrm{C}-\mathrm{H}$ ring deformation vibrations.

FTIR-ATR litter spectra reveal differences in the chemical signature of the two tree species. Differences are found at 1693 , 1200-1250 and $887 \mathrm{~cm}^{-1}$ (different peaks in the FTIR-ATR spectrum of $Q$. pubescens) and these signals can be assigned respectively to carboxylic acids from cutin, $\mathrm{C}-\mathrm{O}$ from alcohols and aromatic structure. Other differences are observed at 2918, 2850, 1732, 1637, 


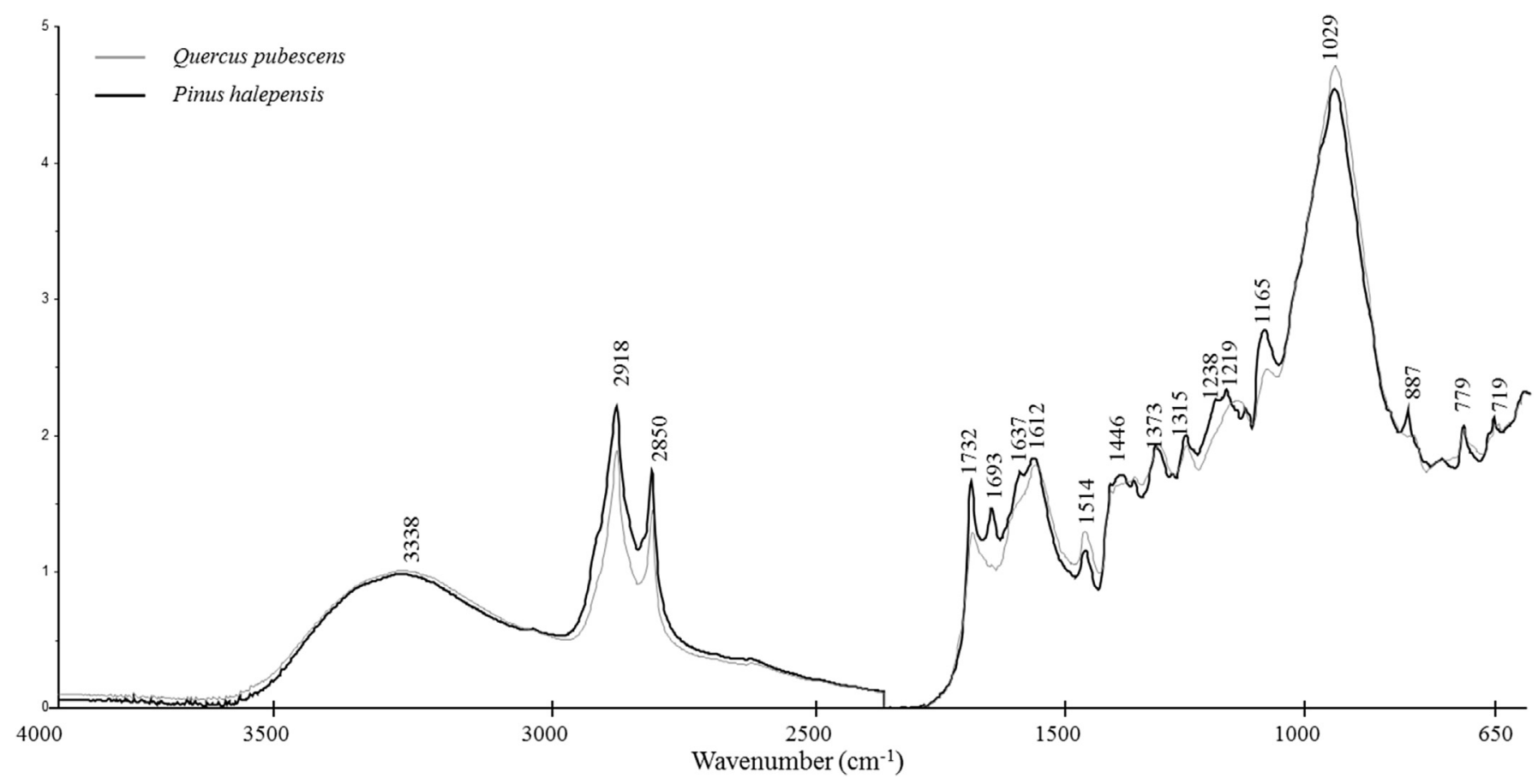

Fig. 2. FTIR-ATR profiles of Pinus halepensis and Quercus pubescens litters at water activity around 0.4.

Table 1

FTIR-ATR assignments of chemical functions to biopolymers and for each figure.

\begin{tabular}{|c|c|c|c|c|c|c|c|c|c|}
\hline Compounds classes & Fig. 2 & $\begin{array}{l}\text { Fig. } 3 b(+) \\
\text { Water }\end{array}$ & $\begin{array}{l}\text { Fig. } 4 \mathrm{~b}(+) \\
\text { Cutin }\end{array}$ & $\begin{array}{l}\text { Fig. } 4 c(+) \\
\text { Polysaccharides }\end{array}$ & $\begin{array}{l}\text { Fig. } 4 \mathrm{c}(-) \\
\text { Aromatic, phenolic } \\
\text { compounds,lignin }\end{array}$ & $\begin{array}{l}\text { Fig. } 5 b(+) \\
\text { Cutin }\end{array}$ & $\begin{array}{l}\text { Fig. } 5 \mathrm{~b}(-) \\
\text { Cellulose, } \\
\text { hemicelluloses }\end{array}$ & $\begin{array}{l}\text { Fig. } 5 c(+) \\
\text { Aromatic, phenolic } \\
\text { compounds, lignin }\end{array}$ & $\begin{array}{l}\text { Fig. } 5 c(-) \\
\text { Oxygenated } \\
\text { compounds }\end{array}$ \\
\hline$v(\mathrm{O}-\mathrm{H}--\mathrm{H})$ & 3338 & 3305 & 3500 & 3525 & & 3446 & 3081 & 3112 & 3428 \\
\hline$v_{\mathrm{a}}\left(\mathrm{CH}_{3}\right) \mathrm{Ar}-\mathrm{O}-\mathrm{CH}_{3}$ & & & & & 2964 & & & 2960 & \\
\hline$v_{a}\left(\mathrm{CH}_{2}\right)$ & 2918 & & 2924 & 2920 & & 2919 & & & 2917 \\
\hline$v_{\mathrm{s}}\left(\mathrm{CH}_{3}\right) \mathrm{Ar}-\mathrm{O}-\mathrm{CH}_{3}$ & & & & & 2869 & & & 2870 & \\
\hline$v_{\mathrm{s}}\left(\mathrm{CH}_{2}\right)$ & 2850 & & 2852 & 2850 & & 2848 & & & 2848 \\
\hline$v(\mathrm{C}-\mathrm{H}) \mathrm{Ar}-\mathrm{O}-\mathrm{CH}_{3}$ & & & & & 2829 & & & 2829 & \\
\hline $\begin{array}{l}v(\mathrm{C}=\mathrm{O}) \text { ester with } \mathrm{H} \\
\text { bonds }\end{array}$ & & & & 1753 & & & 1754 & & \\
\hline $\begin{array}{l}v(\mathrm{C}=\mathrm{O}) \text { saturated } \\
\quad \text { aliphatic ester }\end{array}$ & 1732 & & 1732 & 1724 & & 1732 & & & 1728 \\
\hline $\begin{array}{l}v(\mathrm{C}=\mathrm{O}) \text { acid with } \mathrm{H} \\
\quad \text { bonds }\end{array}$ & 1693 & & 1695 & & 1691 & 1695 & & 1691 & \\
\hline $\begin{array}{l}\delta(\mathrm{HOH}) \text { bending or } \\
v\left(\mathrm{COO}^{-}\right)\end{array}$ & & 1640 & & & & & & & \\
\hline$v(\mathrm{C}=\mathrm{C})$ phenolic acid & 1637 & & & & 1639 & & & 1637 & \\
\hline $\begin{array}{l}v(C=C) \text { aromatic or } \\
\quad \text { conjugated } \\
v(C=C) \text { conjugated }\end{array}$ & 1612 & & & 1593 & & & 1583 & & 1589 \\
\hline $\begin{array}{l}v(\mathrm{C}=\mathrm{C}) \text { aromatic } \\
\quad \text { skeletal }\end{array}$ & 1514 & & & & 1539 & & & 1539 & \\
\hline$\delta\left(\mathrm{CH}_{2}\right)$ scissoring & 1446 & & 1466 & & & 1463 & & & \\
\hline$v(C=C)$ aromatic ring & & & & & 1440 & & & 1444 & \\
\hline$\gamma(\mathrm{C}-\mathrm{H})$ out of plane & 1373 & & & & & & & & \\
\hline$\delta\left(\mathrm{CH}_{2}\right)$ rocking & 1315 & & & & & & & & 1307 \\
\hline $\begin{array}{l}\delta(=\mathrm{C}-\mathrm{H}) \text { in plane } \\
\text { aromatic }\end{array}$ & & & & & 1263 & & & 1257 & \\
\hline$v(C-O)$ alcohol & $\begin{array}{l}1238 \\
1219\end{array}$ & & & 1213,1190 & & & 1211 & & 1209 \\
\hline$v_{a}(C-O-C)$ ester & 1165 & & & & & 1169 & & & \\
\hline$v(\mathrm{C}-\mathrm{O}-\mathrm{C})$ glycosidic & 1029 & & & & & & 1008 & & 1045,1006 \\
\hline $\begin{array}{l}\gamma(=\mathrm{C}-\mathrm{H}) \text { out of plane } \\
\quad \text { aromatic }\end{array}$ & 887 & & & & 885,862 & & & $885,852,800$ & \\
\hline$\delta\left(\mathrm{CH}_{2}\right)$ rocking & 779 & & & & & & & & \\
\hline $\begin{array}{l}\delta\left(\mathrm{CH}_{2}\right) \text { rocking (long } \\
\text { chains) }\end{array}$ & 719 & & 720 & & & 721 & & & \\
\hline$\rho(\mathrm{HOH})$ & & 700 & & & & & & & \\
\hline
\end{tabular}

$(+)$ positive part of PC loading, (-) negative part of PC loading. 
1514 and $1165 \mathrm{~cm}^{-1}$, which can be linked to aliphatic-C (2918, $\left.2850 \mathrm{~cm}^{-1}\right)$, aromatic rings $\left(1637,1514 \mathrm{~cm}^{-1}\right), \mathrm{C}=\mathrm{O}$ stretching of ester functional groups $\left(1732 \mathrm{~cm}^{-1}\right)$ and a $\mathrm{C}-\mathrm{O}-\mathrm{C}$ asymmetricalstretching vibration band from esters $\left(1165 \mathrm{~cm}^{-1}\right)$. Higher peaks appear in the $P$. halepensis spectra than in the spectra from Q. pubescens.
Fig. 3 shows PCA from FTIR-ATR spectra of litter at $\mathrm{a}_{w}$ ranging from 0.4 to 0.45 . PC1 ( $37 \%$ of the variance) clearly shows variations between the samples, explained on the positive part by signals at $2920,2850,1733$ and $1174 \mathrm{~cm}^{-1}$ (Table 1 ), which can be assigned to $-\mathrm{CH}_{2}-, \mathrm{C}=\mathrm{O}$ and $\mathrm{C}-\mathrm{O}-\mathrm{C}$ from fatty esters from cutin. On the positive part of $\mathrm{PC} 2$ (22\% of the variance), projections are explained

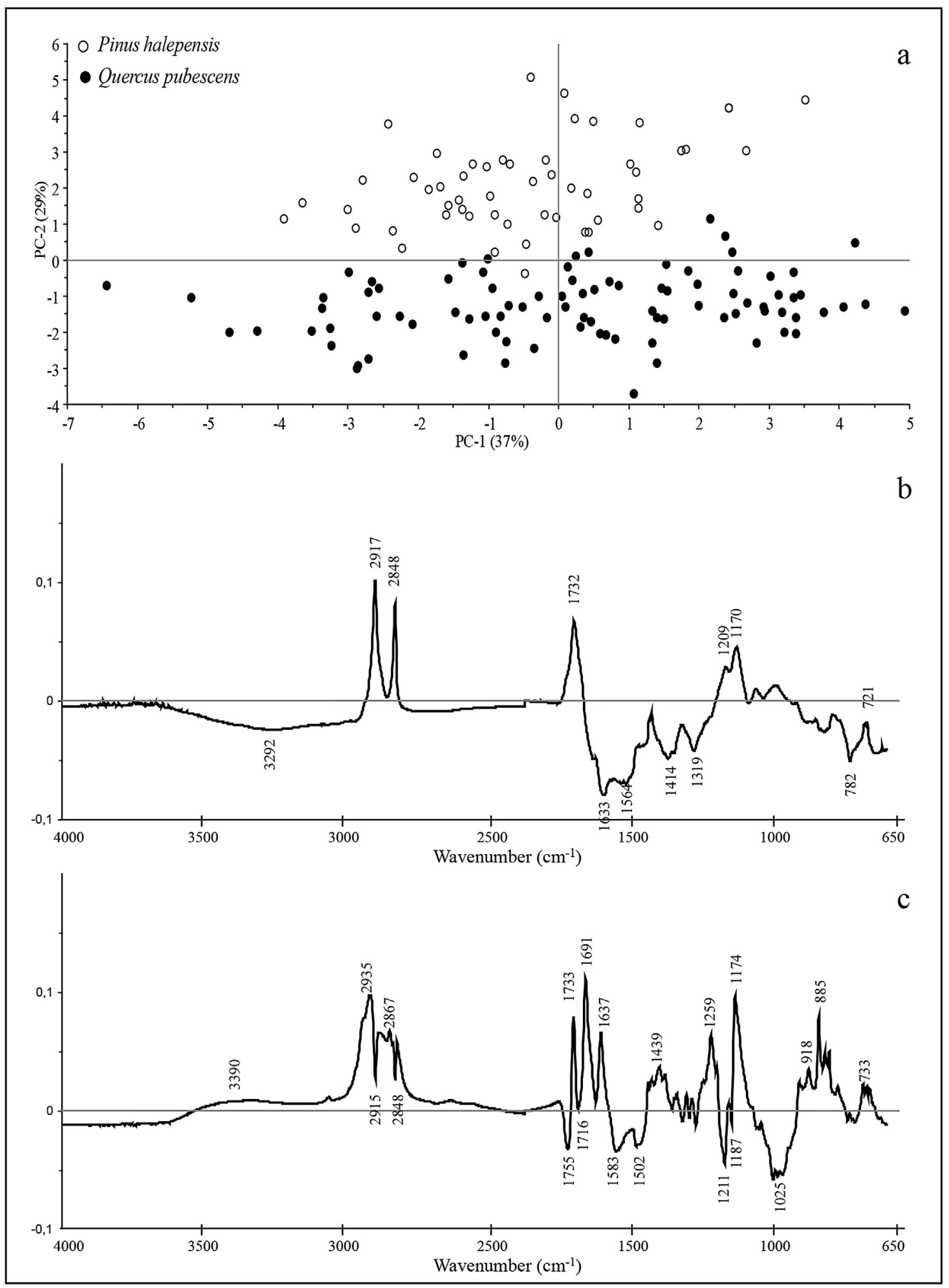

Fig. 3. PCA of litter samples at water activities around 0.4: (PC1-PC2) score plot (a), PC1 loading (b) and PC2 loading (c). 
by signals at 2916, 2849,1749,1716, 1211, 1187 and $1031 \mathrm{~cm}^{-1}$ assigned to $-\mathrm{CH}_{2}-, \mathrm{C}=\mathrm{O}$ and $\mathrm{C}-\mathrm{O}-\mathrm{C}$ from fatty esters and to $\mathrm{C}-\mathrm{O}$ and $\mathrm{C}-\mathrm{O}-\mathrm{C}$ from alcohol and the glycosidic fraction, i.e. polysaccharides. On the negative part of PC2, signals at 1689, 1637, 1477, 1415 and $885 \mathrm{~cm}^{-1}$ linked to $\mathrm{C}=\mathrm{C}$ can be assigned to aromatic rings of lignin. Projections from $Q$. pubescens litters are thus mainly explained by signals from cutin, while those from $P$. halepensis are explained by the chemical signature of aromatic compounds.

\subsection{Understanding interactions between water, $\mathrm{NaCl}$ and the litter} matrix using FTIR-ATR

FTIR-ATR spectra of litters at different $\mathrm{a}_{w}$ and without added $\mathrm{NaCl}$ were first analyzed using principal component analyses (PCA). Water strongly influenced FTIR-ATR spectra: PCA scores on PC1 ( $85 \%$ of the variance) clearly discriminate litter samples at $\mathrm{a}_{w}$ ranging from 0.8 to 1 from the others (Fig. 4a). The projections according to PC1 are explained by IR signals assigned to water bonds (Fig. 4b) i.e. 3305, 1640 and $682 \mathrm{~cm}^{-1}$ (Table 1), indicating that litters can be clearly differentiated by water quantity. An ordination of the projections plotted on PC2 and PC3 (12\% of the variance, data not shown) revealed the same differences in chemical composition between $P$. halepensis and $Q$. pubescens litters as described above.

FTIR-ATR spectra were further analyzed to explore how adding $\mathrm{NaCl}$ modified water adsorption onto the litter matrix. We focused on the spectra from litters with (105 g.L $\mathrm{L}^{-1}$ ) and without added $\mathrm{NaCl}$ and at $\mathrm{a}_{w}$ ranging from 0.5 to 1 , since these values include the part of the sorption isotherm which shifted when $\mathrm{NaCl}$ was added (Fig. 1). As described above, water explains projections on PC1, which supports $70 \%$ of the variance. Projections according to PC2 and PC3 (22\% of variance, Fig. 5a, b and c) allowed discrimination of FTIR-ATR spectra for litters with added $\mathrm{NaCl}$. Moreover, and to a lesser extent, PC2 explains differences between $Q$. pubescens and $P$. halepensis (situated on the negative and the positive part of $\mathrm{PC} 2$ respectively), showing that projections of litters with added $\mathrm{NaCl}$
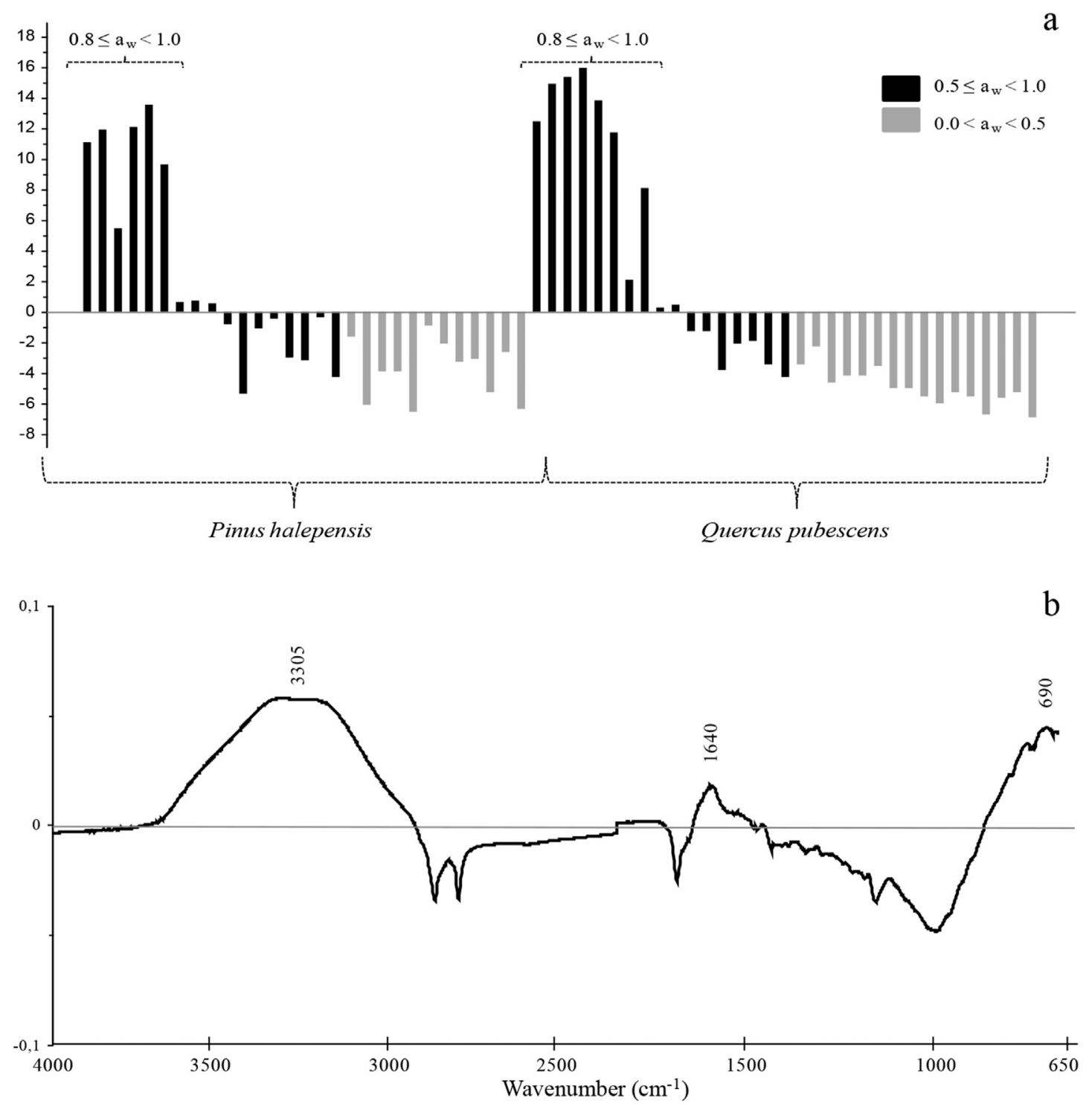

Fig. 4. PCA data from litter samples at different water activities: PC1 score plot (a) and PC1 loading (b). 


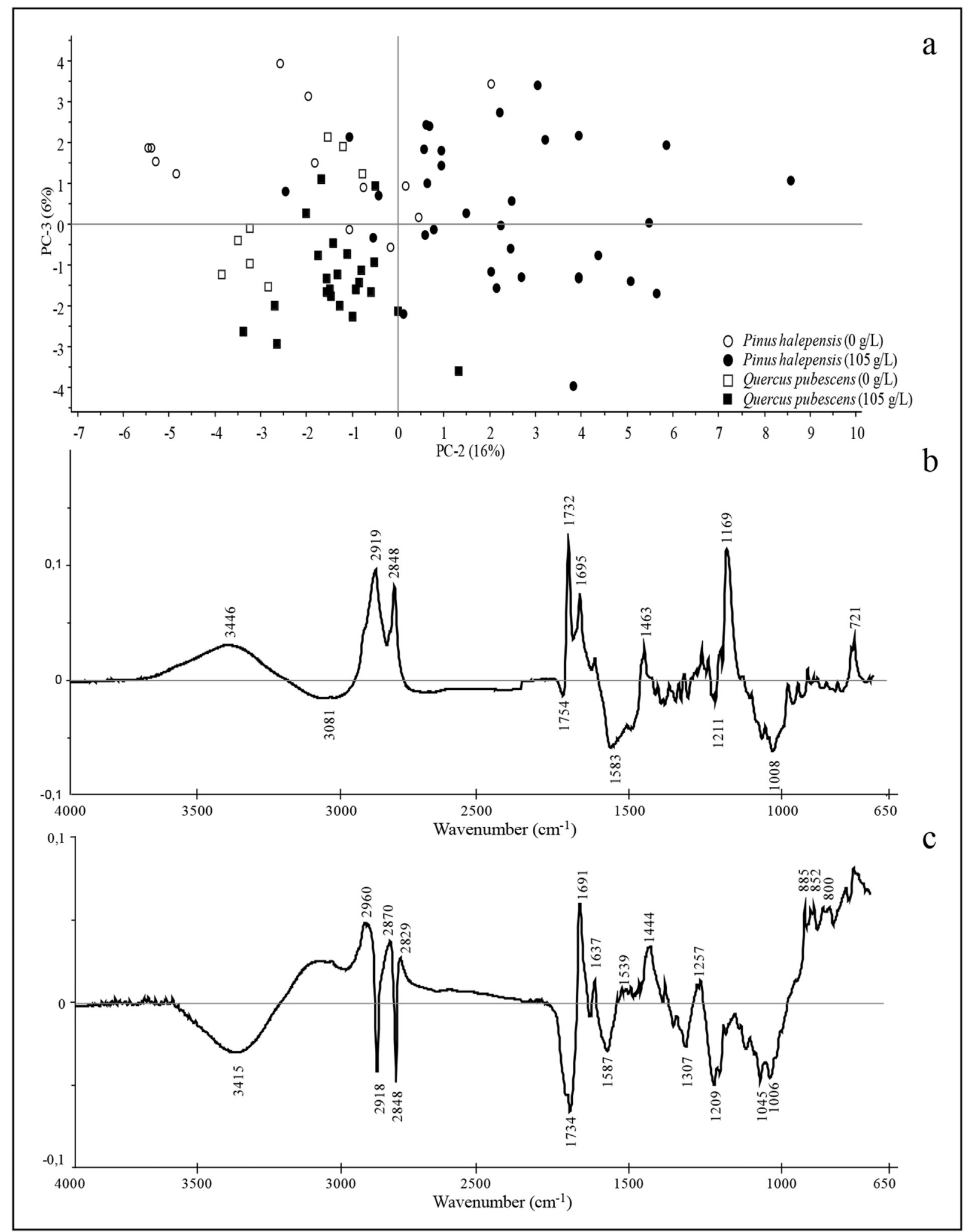

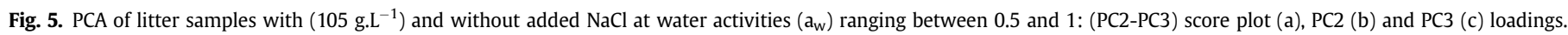


are still differentiated by plant species. For PC2, the signals found at 2916, 2848, 1732, 1693, 1464, 1261, 1172 and $721 \mathrm{~cm}^{-1}$ indicate that signals linked to polysaccharides or cutin explain the distribution of plots for litters with added $\mathrm{NaCl}$.

\subsection{Lipase hydrolytic activities in litters at low water activity with and without osmotic stress}

We measured lipase activities by the microbial communities in both species' litters to follow hydrolase activity variations depending on water availability, both with and without additional osmotic stress. It should be noted that no water was added to the reaction mixture, which means that the water molecules used as substrate by lipases were actually those available in the litter, according to its degree of humidity. The quantity of water for the enzymatic reaction was thus strictly controlled. For both plant species' litters, both with and without added $\mathrm{NaCl}$, lipase activities increased with increasing water availability up to $\mathrm{a}_{w}$ close to 0.9 , and then decreased with higher water availability (Fig. $6 \mathrm{a}$ and b). Interestingly, we found that lipase activities were not significantly affected by litter salinity at an $\mathrm{NaCl}$ concentration of $35 \mathrm{~g} \cdot \mathrm{L}^{-1}$ for either of the vegetal species considered.

\section{Discussion}

The type-II isotherm found for litters of both Quercus pubescens and Pinus halepensis has already been reported for various plant materials such as orange peels and leaves (Kammoun Bejar et al., 2012), rosemary (Bensebia and Allia, 2016) or olive tree leaves (Bahloul et al., 2008). It is characteristic of inorganic or organic porous materials. A similar pattern was found in previous food science studies focusing on model molecules such as casein,
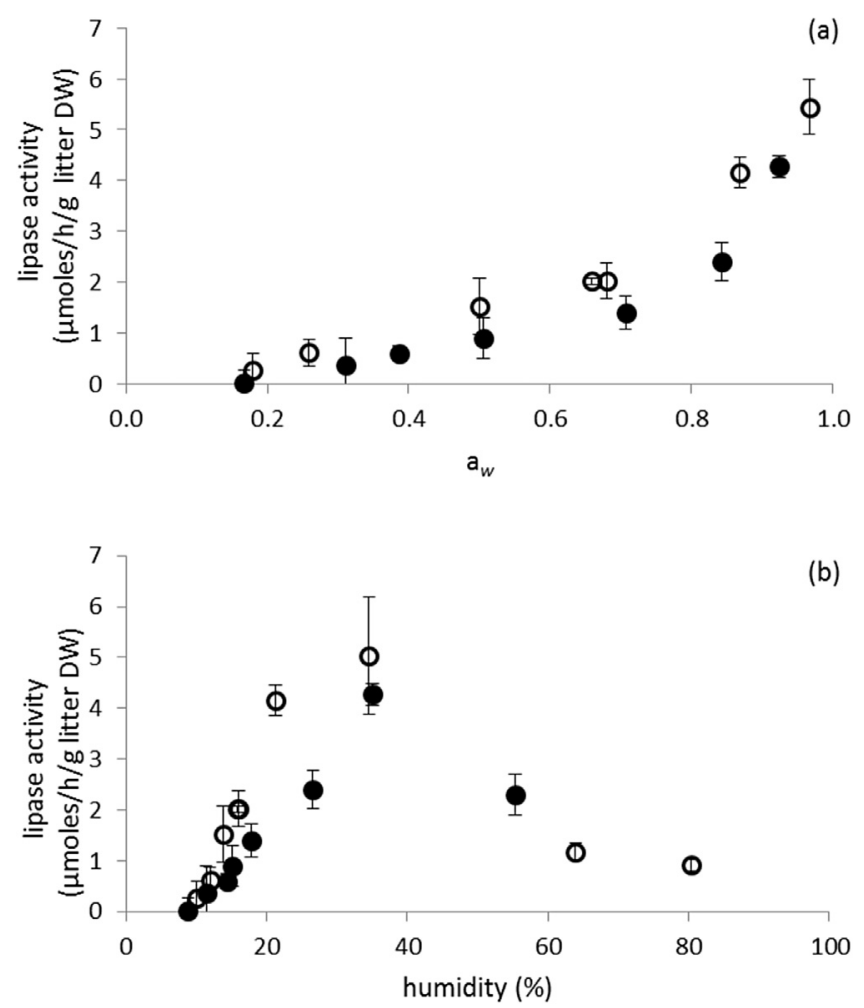

Fig. 6. Lipase hydrolytic activity in Quercus pubescens litter supplemented ( $)$ and not supplemented $(O)$ with an $\mathrm{NaCl}$ solution of 35 g.L $\mathrm{L}^{-1}$ depending on water activity (a) or humidity (b). The same trend was observed in Pinus halepensis litter. lactoglobulin (Fanni et al., 1989; Curme et al., 1990) or on more heterogeneous material such as meat (Kabil et al., 2012). Plant litter's ability to adsorb water is a property of huge importance, enhancing habitat conditions for plants, micro invertebrates and microorganisms in litters and soils (Henry, 2012; Kammer et al., 2013). These microbial communities are responsible for the decomposition of organic matter and sustain major ecological processes such as biogeochemical cycles. Thus, variations in the ability to retain water may strongly influence the sensitivity of this ecosystem compartment -and of the microbial communities it harbors-to desiccation (Chowdhury et al., 2011). Here, we found that the relation between water availability and humidity revealed by sorption isotherms was similar for both plant species. Nor did the differing chemical compositions of the two types of litter, as revealed by FTIR-ATR spectra (signals from cutin were more specifically assigned to $Q$. pubescens litter while those from aromatics to $P$. halepensis). Reina et al. (2001) have found that the proportion of lignin, in combination with cutin and polysaccharides extracted from conifer cuticles, modified sorption isotherms and were responsible for water clustering in the cuticle. Here, our study indicates that litters from two plants with different functional traits (broadleaved vs coniferous) have the same capacity to retain water. It would be valuable to extend this type of study to other Mediterranean species, for instance those typically found in scrubland, such as Pistacia lentiscus or Cistus albidus, to understand whether this sorption isotherm is particularly common in Mediterranean plants' lignocellulosic material. Moreover, material porosity is determinant in surface interactions (Maltini et al., 2003) and sorption isotherms may well differ greatly between litter horizons. While we focused here on the surface horizon (OLF horizon), obviously more exposed to desiccation, further studies could usefully investigate different litter horizons to determine how water sorption potential varies according to depth.

We also aimed at deciphering whether and how $\mathrm{NaCl}$ ions may interact with the litter matrix. FTIR-ATR spectra revealed that signals linked to cellulose or cutin were assigned to samples with added $\mathrm{NaCl}$, probably due to these interactions. Deshpande et al. (2008) described interactions between $\mathrm{NaCl}$ and cellulose and found that sodium ions were particularly bound to polysaccharides, while chloride ions were excluded from the chemical structure. They precisely described these interactions showing that sodium ions can actually bind to cellulose at two sites: the hydroxyl groups of either C6 or C2 of glucose. Thus, the chemical properties of litter, particularly those linked to its degree of decomposition (which may increase the availability of binding sites for ions onto cellulose) may modify these interactions, thereby affecting the quantity of ions that can be adsorbed onto litter. Further studies should identify the interactions between water, ions and the litter matrix in the humic litter horizon, at higher decomposition. Here, when different $\mathrm{NaCl}$ concentrations were added to litters in order to clearly determine the influence of salts on water availability, a shift in sorption isotherms was actually found at $a_{w}$ ranging from 0.75 to 1 . The threshold found $\left(a_{w}=0.75\right)$ can be explained by the fact that below this value, $\mathrm{NaCl}$ crystallizes and can no longer adsorb water molecules. Previous studies (Curme et al., 1990; Fanni et al., 1989) showed that when $\mathrm{NaCl}$ was added to proteins such as casein or $\beta$ lactoglobuline, $\mathrm{NaCl}$ ceased to adsorb water below $\mathrm{a}_{w}=0.75$, actually turning into a crystal. The findings here are of importance, demonstrating that exposure to $\mathrm{NaCl}$ (from 35 g.. $\mathrm{L}^{-1}$ ) aggravates matric stresses (due to desiccation) in litters above a certain $\mathrm{a}_{w}$ threshold (0.75), i.e. above roughly $30 \%$ humidity. In previous studies, Qasemian et al. (2012, 2014) investigated litter microbial functioning in coastal habitats and showed that conductivity monitored in the field in Mediterranean coastal zones can be as high as $1500 \mu \mathrm{S} \mathrm{cm}^{-1}$ in summer. These studies revealed that, even 
at microlocal scales (from 10 to $300 \mathrm{~m}$ from shore), distance from the sea structures functional diversity, and that coastal constraints may limit microbial functioning by decreasing extracellular activities.

In this study, we used lipases to explore to what extent limiting water availability alters hydrolytic activities in litters. Lipases are indeed an interesting enzymatic model, since these enzymes are not denatured in hydrophobic organic solvent such as heptane (Goujard et al., 2009). Consequently, under these particular experimental conditions, water quantity could be controlled in the reaction mixture. Since no water was added to the reaction medium, the quantity of water available for enzyme reactions was actually that found in the litter at various $a_{w}$. Thus, we were able to more accurately determine the interactions between substrates (i.e. both water and $p$-nitrophenyl laurate), enzymes and the vegetal matrix which drive enzyme activity rates under low water content conditions (Farnet et al., 2010; Goujard et al., 2009). We did not compare lipase activities in the two types of litters quantitatively, since variations in the chemical composition of litter are known to shape microbial community structure and in turn the amount of extracellular enzymes produced (Fioretto et al., 2009; Papa et al., 2008). Our objectives here were to understand how water availability may differ between Quercus pubescens and Pinus halepensis litters due to varying interactions between water, litter matrix and salts, according to the chemical composition of tree species. Thus, we investigated whether differences in the trends of lipase activities were actually observable or not. In both litters, lipase activities increased at $\mathrm{a}_{w}$ ranging from 0.6 to 1 , i.e. with increasing water availability. This is a common feature observed with purified lipases: water favors hydrolysis directly, since this is the substrate of the reaction, and indirectly, by fostering enzyme tridimensional conformation (Affleck et al., 1992). Variations in lipase activities with $a_{w}$ were similar in both litters; this is not surprising, given that the same sorption isotherm profile was obtained for Quercus pubescens and Pinus halepensis, indicating that water availability varied in the same way. Therefore, differences in litter chemical composition did not affect lipase activity trends, which can be explained by the absence of modifications in water adsorption onto both types of litter. Lipase activities decreased above $\mathrm{a}_{w}=1$, probably due to the aggregation of enzymes at higher water content. Previous studies pointed out that lipase, for both esterification and hydrolysis activities, decreases with higher $\mathrm{a}_{w}$ and that the threshold varies depending on the solubility of water in the solvent used (Chowdary and Prapulla, 2002; Valivety et al., 1992a). This threshold, and thus the optimal $\mathrm{a}_{w}$ for lipase activity, also depend both on the concentration of substrate (and its solubility variation in the organic phase) and on the intrinsic mass action of water (Valivety et al., 1992a).

It is particularly noteworthy that no differences were observed between lipase activities with and without $\mathrm{NaCl}$. In other words, the decrease in water availability at $\mathrm{a}_{w}$ ranging from 0.7 to 1 , as shown by the sorption isotherms (though this decrease is weak for $\mathrm{NaCl}$ at 35 g.. $\mathrm{L}^{-1}$ ), did not modify the hydrolytic potential of lipases. Usually, a decrease in the activity of soil enzymes due to increased salinity is reported in salinized soils (Rietz and Haynes, 2003, Farnet et al., 2016) due to the effect of osmotic pressure on microbial cells. Qasemian et al. (2014) showed that sea spray exposure can alter microbial activities: the influence of more intense salt exposure in litters close to the sea (and especially during summer drought) stresses microbial communities, leading to lower enzyme activities. However, salts can also directly impact enzymes by modifying their tridimensional conformation, interacting with their active site (which leads to inhibition of catalysis, Farnet et al., 2008) and limiting the quantity of water available. Lipases are known to interact with substrate at organic-aqueous interfaces and thus can remain active at low water availability (Ma et al., 2002; Valivety et al., 1992b). This means that the catalytic potential of such enzymes, which are involved in carbon assimilation and are produced by a large number of microorganisms, is maintained under drastic conditions mimicking the drought and osmotic stress found in the field. Studying enzyme catalysis at low water activities is of particular importance; further work should investigate how other enzymes, such as $\beta$-glycosidase (hydrolysis/transglycosylation), cope with water scarcity (Hansson et al., 2001). However, these investigations need particular experimental conditions, i.e. organic solvent to control quantities of water, requiring further methodological developments to deal with litter.

\section{Conclusion}

This work highlights the importance of studying the mechanisms underlying water sorption/desorption in litter. Our findings demonstrate that water adsorption potential is similar for the two vegetal species considered and that adding $\mathrm{NaCl}$ causes a shift in sorption isotherms above water activity of 0.75 . FTIR-ATR provides useful information about the molecular interactions in such a matrix and reveals that $\mathrm{Na}^{+}$ions are bound to cellulose. Litter is known to be subjected to cycles of dessication/rewetting, and further studies should investigate hysteresis patterns (rehumectation after dessication), as desiccation may modify molecule interactions in the vegetal matrix. In addition, the other litter horizons should be considered, since organic matter transformation probably leads to different molecular interactions and water adsorption potentials of the litter matrix.

\section{Acknowledgements}

We are very grateful to Marjorie Sweetko for improving the English of the manuscript and to I.M. Da Silva for his technical support. This manuscript benefited from the helpful comments of the Editor-in-Chief and the two anonymous reviewers.

\section{Appendix A. Supplementary data}

Supplementary data related to this article can be found at http:// dx.doi.org/10.1016/j.soilbio.2017.06.026.

\section{References}

Affleck, R., Xu, Z.-F., Suzawa, V., Focht, K., Clark, D.S., Dordick, J.S., 1992. Enzymatic catalysis and dynamics in low-water environments. PNAS USA 89, 1100-1104.

Bahloul, N., Boudhrioua, N., Kechaou, N., 2008. Moisture desorption-adsorption isotherms and isosteric heats of sorption of Tunisian olive leaves (Olea europaea L.). Ind. Crops Prod 28, 162-176.

Bensebia, O., Allia, K., 2016. Analysis of adsorption-desorption moisture isotherms of rosemary. J. App. Res. Med. Arom. Plants 3, 79-86.

Boeriu, C.G., Bravo, D., Gosselink, R.J.A., Van Dam, J.E.G., 2004. Characterisation of structure-dependent functional properties of lignin with infrared spectroscopy. Ind. Crops Prod 20, 205-218.

Brunauer, S., Deming, L.S., Teller, E., 1940. On a theory of Van der Walls adsorption of gases. J. Am. Chem. Soc. 62, 1723-1732.

Castro, J., Fernández-Ondoño, E., Rodríguez, C., Lallena, A.M., Sierra, M., Aguilar, J. 2008. Effects of different olive-grove management systems on the organic carbon and nitrogen content of the soil in Jaén (Spain). Soil and Tillage Research 98, 56-67.

Chowdary, G.V., Prapulla, S.G., 2002. The influence of water activity on the lipase catalyzed synthesis of butyl butyrate by transesterification. Process Biochemistry 38, 393-397.

Chowdhury, N., Marschner, P., Burns, R.G., 2011. Soil microbial activity and community composition: impact of changes in matric and osmotic potential. Soil Biol. Biochem 43, 1229-1236.

Coûteaux, M.M., Bottner, P., Berg, B., 1995. Litter decomposition, climate and litter quality. Tree 10, 63-66.

Curme, A.G., Schmidt, S.J., Steinberg, M.P., 1990. Mobility and activity of water in casein model systems as determined by $2 \mathrm{H} \mathrm{NMR}$ and sorption isotherms. J.Food Sci. 55, 430-433. 
Deshpande, M.D., Scheicher, R.H., Ahuja, R., Pandey, R., 2008. Binding strength of sodium ions in cellulose for different water contents. J. Phys. Chem. 112, 8985-8989.

Dubis, E.N., Dubis, A.T., Morzycki, J.W., 1999. Comparative analysis of plant cuticular waxes using HATR FT-IR reflection technique. J. Mol. Struct. 511-512, 173-179.

Fan, M. Dai, D., Huang, B., 2012. Fourier transform infrared spectroscopy for natura fibres. In: Salih, Salih (Ed.), Chapter 3 for Book: Fourier Transform - Materials Analysis. ISBN: 978-953-51-0594-7, InTech.

Fanni, J., Canet, D., Elbayed, K., Hardy, J., 1989. ${ }^{1} \mathrm{H}$ and ${ }^{23} \mathrm{Na}$ NMR relaxation studies of the $\mathrm{NaCl} / \beta$-Lactoglobulin system equilibrated at various water activities. J. Food Sci. 54, 909-916.

Farnet, A.M., Gil, G., Ferré, E., 2008. Effects of pollutants on laccase activities of Marasmius quercophilus, a white-rot fungus isolated from a Mediterranean schlerophyllous litter. Chemosphere 70, 895-900.

Farnet, A.M., Qasemian, L., Gil, G., Ferré, E., 2013. The importance of water availability in the reaction equilibrium of hydrolases in forest litters from a Mediterranean area: a study on lipases. Eur. J. Soil Sci 64, 1-6.

Farnet, A.M., Qasemian, L., Goujard, L., Gil, G., Guiral, D., Ruaudel, F., Ferré, E., 2010. A modified method based on $p$-nitrophenol assay to quantify hydrolysis activities of lipases in litters. Soil Biol. Biochem. 42, 386-389.

Farnet, A.M., Boukhdoud, N., Gros, R., 2016. Distance from the sea as a driving force of microbial communities under water potential stresses in litters of two typical Mediterranean plant species. Geoderma 269, 1-9.

Fioretto, A., Papa, S., Pellegrino, A., Ferrigno, A., 2009. Microbial activities in soils of a Mediterranean ecosystem in different successional stages. Soil Biol. Biochem. 41, 2061-2068.

Giorgi, F., Lionello, P., 2008. Climate change projections for the Mediterranean region. Global and Planetary Change 63, 90-104.

Goujard, L., Ferré, E., Gil, G., Ruaudel, F., Farnet, A.M., 2009. A method to quantify transesterification activities of lipases in litters. J. Microbiol. Meth. 78, 127-130.

Henry, H.A.L., 2012. Soil extracellular enzyme dynamics in a changing climate. Soil Biol. Biochem. 47, 53-59.

Hansson, T., Andersson, M., Wehtje, E., Adlercreutz, P., 2001. Influence of wate activity on the competition between b-glycosidase- catalyzed transglycoslation and hydrolysis in aqueous hexanol. Enz. Microb. Technol. 29, 527-534.

Heredia-Guerrero, J.A., Benitez, J.J., Dominguez, E., Bayer, I.S., Cingolani, R., Athanassiou, A., Heredia, A., 2014. Infrared and Raman spectroscopic features of plant cuticles: a review. Front. Plant Sci. 5 (305), 1-14.

Jolliffe, I.T., 2002. Principal Component Analysis. John Wiley \& Sons, Ltd.

Kabil, E., Aktas, N., Balci, E., 2012. Effect of sodium chloride, sodium nitrite and temperature on desoption isotherms of previously frozen beef. Meat Science 90,
932-938.

Kačurčáková, M., Capek, P., Sasinková, V., Wellner, N., Ebringerová, A., 2000. FT-IR study of plant cell wall model compounds: pectic polysaccharides and hemicelluloses. Carbohydrate Polymers 43, 195-203.

Kammer, P.M., Schoeb, C., Eberhard, G., Gallina, R., Meyer, R., Tschanz, C., 2013. The relationship between soil water storage capacity and plant species diversity in high alpine vegetation. Plant Ecol. Divers 6, 457-466.

Kammoun Bejar, A., Aihoubi, N.B., Kechaou, N., 2012. Moisture sorption isotherms experimental and mathematical investigations of orange (Citrus sinensis) peel and leaves. Food Chem. 132, 1728-1735.

Ma, L., Persson, M., Adlercreutz, P., 2002. Water activity dependence of lipase catalysis in organic media explains successful transesterification reactions. Enz. Microb. Technol. 31, 1024-1029.

Maltini, E., Torreggiani, D., Venir, E., Bertolo, G., 2003. Water activity and the preservation of plant foods. Food Chem. 82, 79-86.

Papa, S., Pellegrino, A., Fioretto, A., 2008. Microbial activity and quality changes during decomposition of Quercus ilex leaf litter in three Mediterranean woods. Appl. Soil Ecol. 40, 401-410.

Pencreac'h, G., Baratti, J.C., 1996. Hydrolysis of $p$-nitrophenyl palmitate in n-heptane by the Pseudomonas cepacia lipase: a simple test for the determination of lipase activity in organic media. Enz. Microb. Technol. 18, 417-422.

Qasemian, L., Guiral, D., Farnet, A.M., 2014. How do microlocal environmental variations affect microbial activities of a Pinus halepensis litter in a Mediterranean coastal area. STOTEN 496, 398-205.

Qasemian, L., Guiral, D., Ziarelli, F., Van Dang, T.K., Farnet, A.M., 2012. Effects of anthracene on microbial activities and organic matter decomposition in a Pinus halepensis litter from a Mediterranean coastal area. Soil Biol. Biochem. 46, $148-154$.

Sofo, A., Manfreda, S., Fiorentino, M., Dichio, B., Xiloyannis, C., 2008. The olive tree: a paradigm for drought tolerance in Mediterranean climates. Hydrology and Earth System Sciences 12, 293-301.

Reina, J.J., Dominguez, E., Heredia, A., 2001. Water sorption-desorption in conifer cuticles: the role of lignin. Physiologia Plantarum 112, 372-378.

Rietz, D.N., Haynes, R.J., 2003. Effects of irrigation-induced salinity and sodicity on soil microbial activity. Soil Biol. Biochem. 35, 845-854.

Valivety, R.H., Halling, P.J., Macrae, A.R., 1992a. Reaction rate with suspended lipase catalyst shows similar dependence on water activity in different organic solvents. Bioch. Biophy. Act. 1118, 218-222.

Valivety, R.H., Halling, P.J., Macrae, A.R., 1992b. Rhizomucor miehei lipase remains highly active at water activity below 0.0001. FEBS Letters 301, 258-260. 